\title{
EXSANGUINATING CEPHALHAEMATOMATA IN AFRICAN NEWBORN INFANTS*
}

\author{
BY \\ RONALD L. VAN DER HORST \\ From the Department of Paediatrics and Child Health, King Edward VIII Hospital, Durban
}

(RECEIVED FOR PUBLICATION NOVEMBER 2, 1962)

Extravasation of blood into the various layers of the scalp in the newborn infant presents different clinical and pathological entities depending on the site of the bleeding (Chorobski and Davies, 1934). For example, the familiar subperiosteal cephalhaematoma in infants rarely causes concern and time alone will resolve the swelling in the vast majority of cases.

The purpose of this paper is to discuss briefly the varieties of cephalhaematoma that may occur and to describe a type of severe and extensive haemorrhage into the scalp tissues encountered in full-term African newborn infants. It seems that this dangerous variety of cephalhaematoma which is not uncommon in the African infant is a great rarity in European infants, but the reason for this racial difference remains obscure.

During the course of three months, 10 cases of severe exsanguinating cephalhaematoma were seen, nine of which were of the subaponeurotic variety. Details of these cases are described.

\section{Types of Haematoma}

Haemorrhage into the scalp tissues may be classified according to the anatomical distribution of the haematoma: (a) Subcutaneous cephalhaematoma; (b) subperiosteal cephalhaematoma; (c) subaponeurotic cephalhaematoma. With the introduction of the vacuum extractor in obstetric practice, cases of cephalhaematoma have been described which conform to the above as well as (d) cephalhaematomata which transcend suture lines and may be due to ripping up of the pericranium and its processes in between individual skull bones (Boon, 1961).

It is probable that there will be an increase in the frequency of these haematomata with the wider use of this instrument.

* Based on a paper presented at the Fifth Congress of the South African Paediatric Association.
Subcutaneous Haematoma. The upper three layers of the scalp are so adherent to one another that they may be considered as one layer. Haemorrhage into them is never extensive because expansion is limited by the dense fibrous tissue. This type of haemorrhage is only very rarely seen in the newborn.

Subperiosteal Cephalhaematoma. Each bone of the cranium is enveloped by an individual sheath of periosteum. This is loosely attached to the external surface of the skull bones, but it is fixed at the suture lines and the temporal fossae. An accumulation of blood in the subperiosteal space, therefore, is sharply limited by the suture lines.

Naegele (1819) (quoted by Virchow, 1863) was the first to describe this collection of blood on the head under the description of 'tumor cranii sanguineus'. Burchard (1837) described the condition as 'De tumore cranii recens natorum sanguineo'. It is only to this relatively common subperiosteal cephalhaematoma that reference is made in most modern obstetric and paediatric textbooks.

Davies (1894) stated that occasionally haemorrhage into subperiosteal cephalhaematoma may be severe. Schaffer (1960) also mentions that a few subperiosteal cephalhaematomata may attain a great size from blood loss into them and that the resulting anaemia may be severe enough to require blood transfusion. On the other hand Sanford and Grulee (1960) observe that anaemia does not occur in this condition and Potter (1961) makes no mention of significant blood loss. Severe anaemia resulting from this type of cephalhaematoma is probably very rare, although one such case in this series required a blood transfusion (Fig. 1 and Table 2).

Subaponeurotic Cephalhaematoma. It is with this type of cephalhaematoma that this report is mainly concerned. The loose connective areolar tissue layer of the scalp is tenuous and delicate, forming a potential space where blood may collect 
(Fig. 2). Emissary veins connecting the venous sinuses in the skull with the veins of the scalp traverse the area. A collection of blood in this space can spread without difficulty over the whole of the skull, limited only by the attachment of the epicranius and the galea aponeurotica. It may, therefore, extend posteriorly to the superior nuchal line, laterally to the zygomatic arch, and anteriorly into the root of the nose and the upper eyelids because the frontalis muscle has no attachment to bone.

Naegele (1819) (quoted by Virchow, 1863) differentiated this 'false' cephalhaematoma from the 'true' subperiosteal cephalhaematoma. West (1874) describes two cases, and in their textbook, Ashby and Wright (1899) refer to 'cephalhaematoma externum, subaponeurotic variety' but without discussion. Isolated case reports have appeared from time to time (Zamazal, 1898; Aballí, Banús, de Lamerens and Rozengvaig, 1959; Leonard and Anthony, 1961). Clifford (1939) tabulated 26 cases of spontaneous haemorrhage into the scalp tissues under the heading of 'haemorrhagic disease', but did not give other details. In the French literature, Venezia and Jahier (1959) describe four cases of 'subcutaneous' haematoma in the newborn, and Bernard, Sansot and Rapezzi (1960) describe five more cases. These cases appear to be the same as those described in this paper. However, these authors fail to identify specifically the anatomical site of the bleeding.

No mention of subaponeurotic haematoma could be found in standard paediatric and obstetric textbooks. Recently, however, Leonard and Anthony

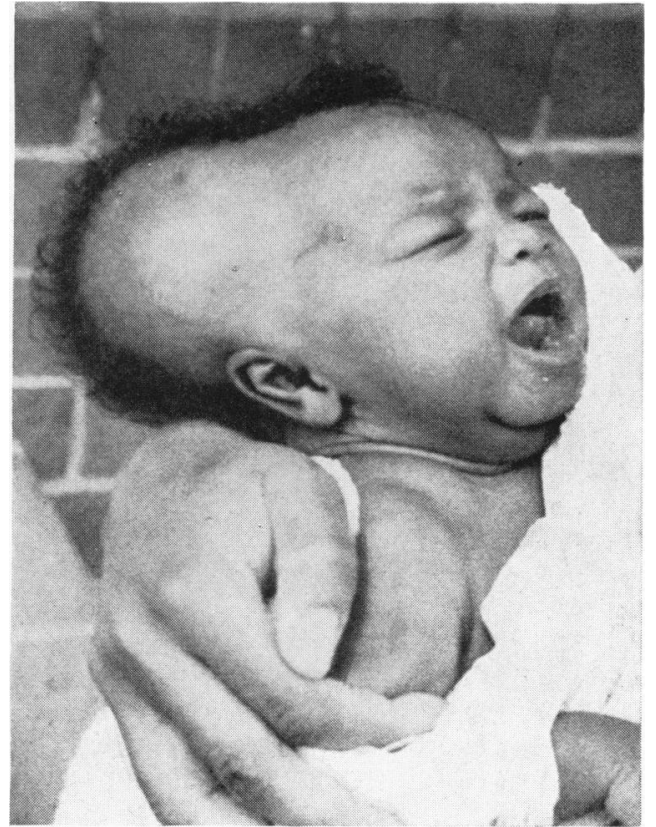

FIG. 1.-Case 10, showing extensive subperiosteal cephalhaematoma.

(1961) emphasized that haemorrhage might be great enough to cause shock, anaemia and hyperbilirubinaemia. Their one case of subaponeurotic cephalhaematoma in a Negro infant developed an anaemia with a haemoglobin of $3.6 \mathrm{~g} . / 100 \mathrm{ml}$. The serum bilirubin rose to $22 \mathrm{mg}$. $/ 100 \mathrm{ml}$. so that an exchange transfusion became necessary.

Fig. 2.-Coronal section of the scalp showing blood extravasated into the subaponeurotic space. In addition, a small subperiosteal haematoma is present. (This section was made from an infant who is not included in this series.) 


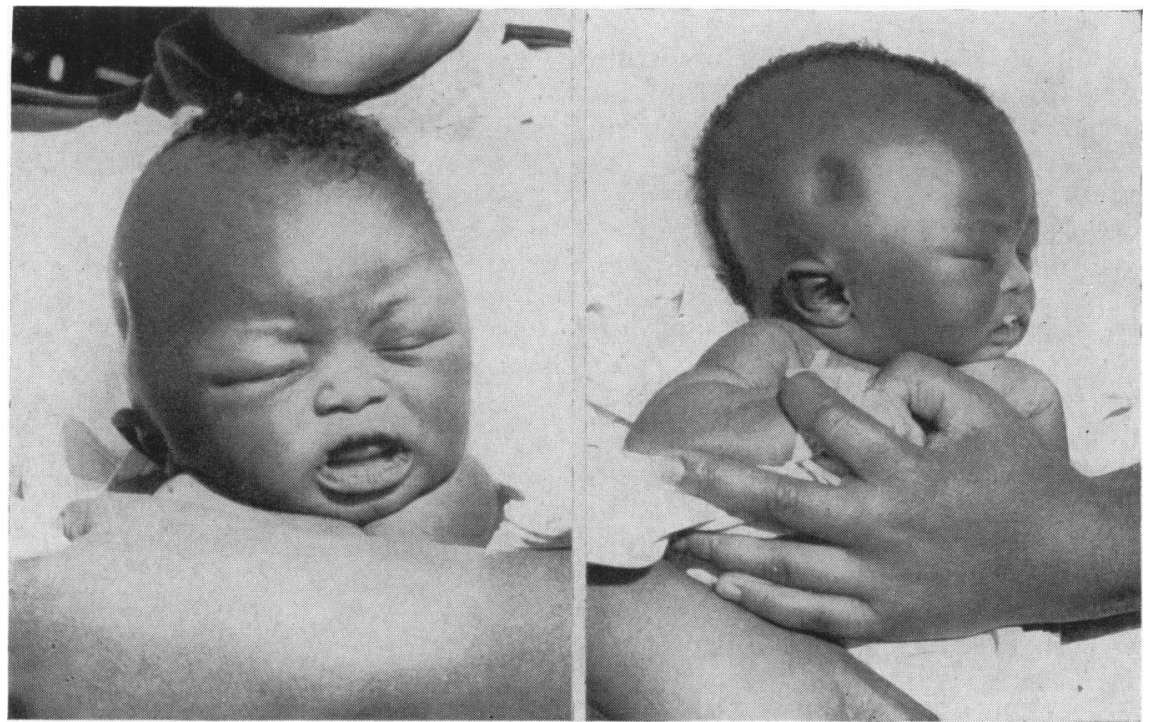

FIG. 3.-Front and side views of an infant with extensive subaponeurotic cephalhaematoma (Case 2).

\section{Clinical Description of Subaponeurotic Cephalhaematoma}

Infants with haemorrhage into the subaponeurotic space present a striking and easily recognizable clinical picture (Figs 3 and 4).

The previous obstetric history does not follow any consistent pattern and indeed may be normal
(Table 1). The position and presentation of the foetus in utero and the type of labour and delivery do not appear to influence the occurrence of bleeding.

The infant is well at birth. Apart from a caput succedanum which is not always present, the head is not abnormal in shape. In 12 to 72 hours, the

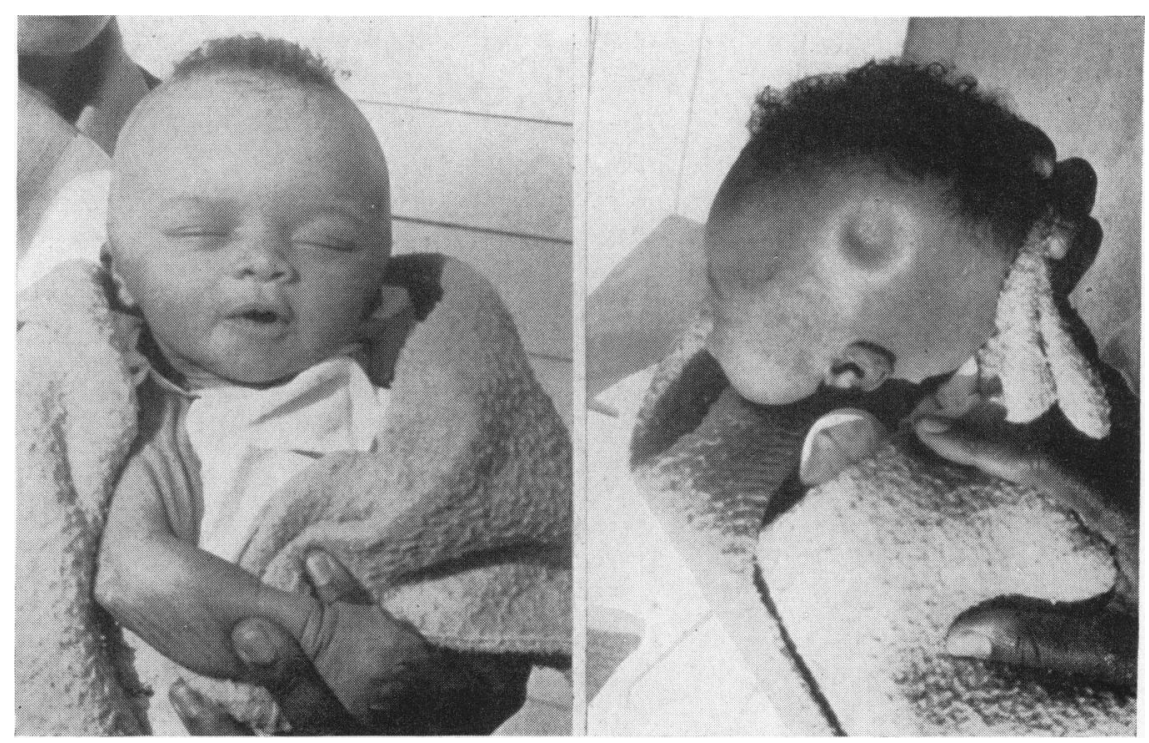

FIG. 4.-Front and side view of an infant with extensive subaponeurotic cephalhaematoma (Case 5). 
TABLE 1

OBSTETRIC DATA

\begin{tabular}{|c|c|c|c|c|}
\hline Case & $\begin{array}{l}\text { Previous Full-term } \\
\text { Pregnancies of Mother }\end{array}$ & $\begin{array}{l}\text { Method of Present } \\
\text { Delivery }\end{array}$ & $\begin{array}{l}\text { Reason for Method of } \\
\text { Delivery }\end{array}$ & $\begin{array}{l}\text { Weight of } \\
\text { Infant }\end{array}$ \\
\hline 1 & 6 & $\begin{array}{l}\text { Lower uterine segment caesarian } \\
\text { section }\end{array}$ & $\begin{array}{l}\text { Oedema of cervix } \\
\text { Prolonged labour }\end{array}$ & 7 lb. 12 oz. $(3.5 \mathrm{~kg})$. \\
\hline 2 & 2 & $\begin{array}{l}\text { Lower uterine segment ceasarian } \\
\text { section }\end{array}$ & $\begin{array}{l}\text { Two previous lower uterine } \\
\text { segment caesarian sections }\end{array}$ & 8 lb. 13 oz. (3.9 kg.) \\
\hline $\begin{array}{l}3 \\
4 \\
5 \\
6 \\
7\end{array}$ & $\begin{array}{l}0 \\
0 \\
0 \\
4 \\
0\end{array}$ & $\begin{array}{l}\text { Normal vertex delivery } \\
\text { Forceps } \\
\text { Normal vertex delivery } \\
\text { Normal vertex delivery } \\
\text { Normal vertex delivery plus }\end{array}$ & $\begin{array}{l}\text { Normal } \\
\text { Delay in second stage } \\
\text { Normal } \\
\text { Normal } \\
\text { Cephalo-pelvic disproportion }\end{array}$ & 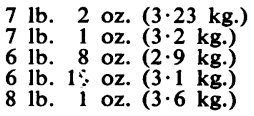 \\
\hline 8 & 2 & $\begin{array}{l}\text { symphysiotomy } \\
\text { Lower uterine segment caesarian } \\
\text { section }\end{array}$ & $\begin{array}{l}\text { Two previous lower uterine } \\
\text { segment caesarian sections }\end{array}$ & 6 lb. 9 oz. $(2.9$ kg. $)$ \\
\hline 9 & 1 & Forceps and episiotomy & $\begin{array}{l}\text { One previous lower segment } \\
\text { caesarian section }\end{array}$ & 8 lb. 0 oz. $(3.6$ kg. $)$ \\
\hline 10 & 0 & Normal vertex delivery & Normal & $6 \mathrm{lb} .4 \mathrm{oz} .(2 \cdot 8 \mathrm{~kg})$. \\
\hline
\end{tabular}

head begins to enlarge. The extent and persistence of the bleeding determines the shape and size of the head. The blood may track to the most dependent part so that the swelling on one side of the head is greater than the other. The whole scalp may be distorted by blood but the extent of the swelling is limited by the attachments of the occipitofrontalis muscle and galea aponeurotica. The consistency of the swelling depends on the amount of bleeding. It may be tense and firm to the touch or pit easily on pressure. Pre-auricular swelling mimics enlargement of the parotid gland until palpation excludes it. The widespread distribution of the haemorrhage often produces a grotesque facial appearance which easily differentiates it from the strictly localized subperiosteal cephalhaematoma. The infant rapidly becomes pale and shocked and death may occur unless blood is replaced without delay.

The anaemia is sufficiently severe in this subaponeurotic variety of cephalhaematoma to require immediate blood transfusion in almost every case. The extent of the haemorrhage is reflected in the low haemoglobin figures in Table 2. No other cause for the anaemia could be found in any of these cases.

\section{Haemorrhagic Disease of the Newborn and Haemorrhages of the Scalp}

Townsend in 1894 introduced the term 'haemorrhagic disease of the newborn'. This entity included bleeding in the newborn period unrelated to trauma, infection or disease. This definition has lost some of its original significance in the light of recent knowledge.

Normally the prothrombin level is diminished at birth and falls further on the second to the fourth day. Similar deficiencies of factors VII, IX and X occur attributable to diminished absorption of vitamin $\mathrm{K}$ from the intestine as well as insufficient synthesis and utilization of vitamin $K$ by the immature liver of the infant. The present knowledge of clotting factor deficiencies has broadened the concept of haemorrhagic disease of the newborn. It might be defined today as a syndrome of internal and external bleeding, unrelated to severe trauma, anoxia or infection, associated with disturbances in the blood clotting mechanism in both the first and second phases.

The observation that cephalhaematoma occur from the second to the fourth day and not immediately after birth suggests that haemorrhagic disease of the newborn is probably responsible for the bleeding. Neonatal haemorrhage from the rare familial deficiency of clotting factors must be differentiated. Apart from the normal process of labour, trauma does not appear to be a major factor in causing the haemorrhage.

Prevention, Management and Treatment. There now appears to be some doubt as to whether the

TABLE 2

HAEMOGLOBIN AND HAEMATOCRIT LEVELS

\begin{tabular}{c|c|c|c|c}
\hline Case & $\begin{array}{c}\text { Type of } \\
\text { Haematoma }\end{array}$ & $\begin{array}{c}\text { Haemoglobin } \\
(\mathrm{g} . / 100 \mathrm{ml})\end{array}$ & $\begin{array}{c}\text { Haemoglobin } \\
(\%)\end{array}$ & $\begin{array}{c}\text { Haematocrit } \\
(\%)\end{array}$ \\
\cline { 2 - 3 } 1 & S.A. & $5 \cdot 5$ & 36 & 17 \\
2 & S.A. & $3 \cdot 9$ & 26 & 13 \\
3 & S.A. & $4 \cdot 6$ & 31 & - \\
4 & S.A. & $8 \cdot 3$ & 55 & - \\
5 & S.A. & $7 \cdot 6$ & 51 & 15 \\
6 & S.A. & $5 \cdot 1$ & 35 & 27 \\
7 & S.A. & $9 \cdot 0$ & 60 & 16 \\
8 & S.A. & $5 \cdot 6$ & 38 & 13 \\
9 & S.A. & $5 \cdot 4$ & 37 & \\
10 & S.P. & $3 \cdot 8$ & 26 & \\
\hline
\end{tabular}

S.A. = Subaponeurotic cephalhaematoma S.P. = Subperiosteal cephalhaematoma. 
TABLE 3

VITAMIN K THERAPY IN RELATION TO BLEEDING

\begin{tabular}{c|c|c}
\hline Case & Age When Vitamin K Given & $\begin{array}{c}\text { Age When Seen } \\
\text { (hrs.) }\end{array}$ \\
\hline 1 & 44 & 44 \\
2 & Birth & 45 \\
3 & 50 & 50 \\
4 & Birth & 54 \\
5 & 63 & 63 \\
6 & 5 days & 5 days \\
7 & Birth & 24 \\
8 & Birth & 36 \\
9 & 32 & 54 \\
10 & 5 days & 5 days \\
\hline
\end{tabular}

TABLE 4

STUDIES IN COAGULATION

\begin{tabular}{|c|c|c|c|}
\hline Case & $\begin{array}{l}\text { Prothrombin } \\
\text { Index }(\%)\end{array}$ & $\begin{array}{c}\text { Platelets } \\
\text { per c.mm. }\end{array}$ & $\underset{(\mathrm{mg} . / 100 \mathrm{ml} .)}{\text { Fibrinogen }}$ \\
\hline $\begin{array}{r}1 \\
2 \\
3 \\
4 \\
5 \\
6 \\
7 \\
8 \\
9 \\
10\end{array}$ & $\begin{array}{c}0 \\
0 \\
0 \\
\text { Not done } \\
\text { Not done } \\
0 \\
0 \\
0 \\
\text { Not done } \\
0\end{array}$ & $\begin{array}{c}190,000 \\
124,000 \\
\text { Normal } \\
\text { Not done } \\
\text { Not done } \\
191,000 \\
345,000 \\
\text { Normal } \\
\text { Normal } \\
\text { Normal }\end{array}$ & $\begin{array}{c}171 \\
107 \\
86 \\
\text { Not done } \\
\text { Not done } \\
\text { Not done } \\
115 \\
113 \\
\text { Not done } \\
\text { Not done }\end{array}$ \\
\hline
\end{tabular}

TABLE 5

EXTENT OF HYPERBILIRUBINAEMIA

\begin{tabular}{c|c|c}
\hline Case & Peak Day & $\begin{array}{c}\text { Peak Unconjugated Bilirubin } \\
\text { (mg./100 ml.) }\end{array}$ \\
\hline 1 & 4 & $11 \cdot 2$ \\
2 & 5 & $3 \cdot 4$ \\
3 & 5 & $12 \cdot 6$ \\
4 & 3 & $2 \cdot 4$ \\
5 & 3 & $4 \cdot 8$ \\
6 & 6 & $15 \cdot 5$ \\
7 & 4 & $5 \cdot 3$ \\
8 & 4 & $4 \cdot 0$ \\
9 & 5 & $14 \cdot 0$ \\
10 & Not done & Not done \\
\hline
\end{tabular}

administration of vitamin $\mathrm{K}$ to a woman just before or during labour will prevent haemorrhagic disease in her newborn infant. The policy at this hospital is to administer vitamin $K$ to the babies and not to the mothers. A dose of $1 \mathrm{mg}$. vitamin $K_{1}$ is used. However, many babies are admitted to hospital after delivery at home without medical supervision and the administration of vitamin $\mathrm{K}$. Four of the 10 infants in this series received vitamin $\mathrm{K}$ at birth but bled in spite of this. Two infants who were born at home were given vitamin $\mathrm{K}$ at the time of admission to hospital. In the four remaining cases, administration of vitamin $\mathrm{K}$ was inadvertently omitted at birth, but this was given when the cephalhaematoma developed (Table 3).

Prothrombin indices revealed no clot in 60 seconds as compared to controls in all cases so far studied.
Estimation of the number of platelets and quantity of fibrinogen revealed these to be within the normal range (Table 4).

All infants in this series were transfused with packed cells of fresh blood via the umbilical vein, $10 \mathrm{ml}$. per $\mathrm{lb}$. body weight being given to each infant. One infant had to have a second transfusion because of persistent bleeding into the scalp tissue in spite of vitamin $\mathrm{K}$ and an initial transfusion. Blood transfusion was deemed necessary in the presence of shock or if the haemoglobin level was $60 \%(9 \mathrm{~g}$./ $100 \mathrm{ml}$.) or less. Milder cases with a haemoglobin above this level and not included in this review were not given a blood transfusion unless there was associated shock. In all transfused cases the anaemia was adequately corrected and there was no mortality. Infants were carefully examined for jaundice and daily plasma bilirubin levels were determined. In none of the infants did the degree of hyperbilirubinaemia warrant an exchange transfusion (Table 5).

\section{Summary}

The various types of cephalhaematoma which may occur in the newborn infant are described with special reference to the subaponeurotic variety. The clinical features of exsanguinating cephalhaematoma are described in 10 infants. Nine of these infants had subaponeurotic cephalhaematoma and one infant had a subperiosteal cephalhaematoma.

It is emphasized that subaponeurotic cephalhaematoma, which is not uncommon in the African infant, may cause dangerous haemorrhage requiring immediate blood transfusion. It seems that this extensive type of scalp haemorrhage is extremely rare in European infants but the reason for this racial difference is not clear.

With the introduction of the vacuum extractor to obstetric practice, it is possible that the incidence of exsanguinating subaponeurotic cephalhaematoma will increase.

A possible relation between exsanguinating cephalhaematoma and a disorder in coagulation is postulated. Further investigations are indicated in order to determine this relation more precisely.

I wish to thank Professor H. L. Wallace, Drs. N. M. Mann and J. C. Simson for reading the manuscript and for their helpful advice, encouragement and criticism. I also wish to thank Mr. Stuart for Fig. 2.

\section{REFERENCES}

Aballi, A. J., Banús, V. L., de Lamerens, S. and Rozengvaig, S. (1959). Coagulation studies in the newborn period. III Hemorrhagic disease of the newborn. A.M.A. Amer. J. Dis. Child., 97, 524.

Ashby, H. and Wright, G. A. (1899). The Diseases of Children, p. 19. Longmans Green, London. 
Bernard, R., Sansot, M. and Rapezzi (1960). Anémie par hématome extensif du cuir chevelu chez le nouveau-né. Pédiatrie, 15, 588.

Boon, W. H. (1961). Vacuum extraction in obstetrics. Lancet, 2, 662 .

Burchard (1837). Cited by West, C. (1874).

Chorobski, J. and Davies, L. (1934). Cyst formations of the skull. Surg. Gynec. Obstet., 58, 12.

Clifford, S. H. (1939). Hemorrhagic disease of the newborn. J. Pediat., 14, 333

Davies, E. P. (1894). In Starr's An American textbook of the Diseases of Children, p. $69 . \quad$ F. J. Redman, London.

Leonard, S. and Anthony, B. (1961). Giant cephalhematoma of the newborn with hemorrhagic disease and hyperbilirubinemia. newborn with hemorrhagic

Amer. J. Dis. Child., 101, 170 .
Naegele (1819). Med. Chir. Quoted by Virchow (1863)

Potter, E. L. (1961). Pathology of the Fetus and Infant, 2nd ed., p. 94. Year Book Medical Publishers, Chicago.
Sanford, H. N. and Grulee, C. G. (1960). Brennerman-McQuarrieKelley Practice of Pediatrics, ed. V. C. Kelley, Vol. 1, Chap. 42, p. 63. Prior, Hagerstown, Maryland.

Schaffer, A. J. (1960). Diseases of the Newborn, p. 600 . Saunders, London.

Townsend, C. W. (1894). Haemorrhagic diseases of the newborn Arch. Pediat., 11, 559

Venezia, R. and Jahier, C. (1959). Sur une forme clinique particulière de la maladie hémorragique du nouveau-né: l'hématome sous-cutané crânien extensif. Pédiatrie, 14, 772.

Virchow, R. (1863). Die krankhaften Geschwülste, Vol. 1, p. 130. August Hirschwald, Berlin.

West, C. (1874). Lectures on the Diseases of Infancy and Childhood 6 th ed., p. 60 . Longmans Green, London.

Zamazal, J. (1898) Ein Fall von aussergewöhnlich grossem Cephalhämatom bei einem Neugeborenen. Wien. med Wschr., 49, 240. 